\title{
Dietary Flavonoids Luteolin and Quercetin Suppressed Cancer Stem Cell Properties and Metastatic Potential of Isolated Prostate Cancer Cells
}

\author{
PEI-HSUN TSAI ${ }^{1 *}$, CHIA-HSIUNG CHENG ${ }^{2 *}$, CHUN-YU LIN $^{1}$, YING-TANG HUANG ${ }^{3}$, LUNG-TA LEE ${ }^{4}$, \\ CHITHAN C. KANDASWAMI ${ }^{5}$, YO-CHUEN LIN ${ }^{1}$, KEVIN PO-HAO LEE ${ }^{2}$, CHIN-CHUN HUNG $^{6}$, \\ JIUAN-JIUAN HWANG ${ }^{7}$, FERNG-CHUN KE ${ }^{8}$, GEEN-DONG CHANG ${ }^{1}$ and MING-TING LEE ${ }^{1,3}$ \\ ${ }^{1}$ Institute of Biochemical Sciences, National Taiwan University, Taipei, Taiwan, R.O.C.; \\ ${ }^{2}$ Department of Biochemistry and Molecular Cell Biology, School of Medicine, College of Medicine, \\ Taipei Medical University, Taipei, Taiwan, R.O.C.; \\ ${ }^{3}$ Department of Marine Biotechnology, National Kaohsiung Marine University, Kaohsiung, Taiwan, R.O.C.; \\ ${ }^{4}$ Department of Nursing, Ching-Kuo Institute of Management and Health, Keelung, Taiwan, R.O.C.; \\ ${ }^{5}$ Castle Hills Health Center, Saskatoon, SK, Canada; \\ ${ }^{6}$ Institute of Biological Chemistry, Academia Sinica, Taipei, Taiwan, R.O.C.; \\ ${ }^{7}$ Institute of Physiology, National Yang-Ming University, Taipei, Taiwan, R.O.C.; \\ ${ }^{8}$ Institute of Molecular and Cellular Biology, National Taiwan University, Taipei, Taiwan, R.O.C.
}

\begin{abstract}
A highly invasive Du145-III subline was isolated by three successive passages of the parental Du145 prostate tumor cell line (Du145-P) through a Boyden chamber with matrigel-coated membrane support. Dul45-III cells showed great invasion potential based on their increased ability to spread/migrate and enhanced expression/secretion of the matrix metalloproteinase 9 (MMP9). Du145-III cells exerted vasculogenic mimicry (VM) properties, reminiscent of endothelial cell characteristics and expressed elevated levels of cancer stem cell (CSC) markers, including Nanog, Sox2, $C D 44$ and $A B C G 2$ and ability to self-renew. Of prominence, $M M P 9$ was required for the induction of VM and for increased stemness in Du145-III cells. Using Du145-III as a model, the effects of dietary flavonoids, luteolin and quercetin, were evaluated on stemness and invasion capacity of Du145-III cells in relation to JNK signaling pathway
\end{abstract}

*These Authors contributed equally to this study.

Correspondence to: Dr. Ming-Ting Lee, Institute of Biological Chemistry, Academia Sinica 128, Sec 2, Academia Rd., Taipei (11529), Taiwan, tel: +886-2-2785-5696 ext.5140, e-mail: mtlee@gate.sinica.edu.tw; Dr. Geen-Dong Chang, Institute of Biochemical Sciences, National Taiwan University, No. 1, Sec. 4, Roosevelt Rd., Taipei (10617), Taiwan, R.O.C. Tel: +886 233664071, e-mail: gdchang@ntu.edu.tw

Key Words: Luteolin, quercetin, prostate cancer, cancer stem cell, metastasis, vasculogenic mimicry. activation. These flavonoids depressed the malignancy of highly invasive Du145-III cells, VM, anchorage-independent spheroid formation and expression of certain CSC markers. Since luteolin and quercetin were able to target CSC cells and prevent cancer cell invasiveness, may serve as potential anti-angiogenesis and anti-metastasis agents.

Prostate cancer, one of the most common cancers afflicting males in developed countries, is the third leading cause of cancer mortality in men (1). This type of cancer is often fatal once it spreads to other parts of the body, particularly to lung and bone tissues. Currently, there is not an effective and reliable therapy for metastatic prostate cancer with a definitive survival benefit. Towards this aim, it is imperative to develop more efficacious and robust therapeutic options. The inhibition of tumor invasion and metastatic processes appears to be a valuable approach toward cancer therapy.

Matrix metalloproteinases (MMPs) are zinc-dependent endopeptidases that function in extracellular matrix remodeling and at least $28 \mathrm{MMP}$ genes have been identified (2). MMPs are instrumental in triggering tumor progression and in advancing metastasis in invasive cancers (3). It is considered that the remodeling of extracellular matrix facilitates tumor cell migration and provides the requisite microenvironment for tumor growth. MMPs possess additional important functions, which include modulation of growth factors and cell surface receptors (4). The collective and multifaceted activities of MMPs are deemed crucial for cancer progression. Enhanced expression and activation of 
key MMPs compared to normal tissues is a hallmark of almost all human cancers (3), suggesting that MMPs play a vital role in the initiation and progression of metastasis. MMPs are considered to facilitate the penetration of prostate cancer cells into the blood and lymph vessels and to mediate angiogenesis $(5,6)$. This could be attributed to MMPmediated release of angiogenic factors, such as the vascular endothelial growth factor (VEGF) (7). Previous studies have documented an association between the elevated expression of MMPs (including MMP2, MMP7, MMP9, MMP15 and MMP26) and the progression of malignant prostate carcinomas (8). Accordingly, manipulation of secretion, synthesis and/or the activity of MMPs in cancers may inhibit tumor progression.

Recently, an alternative mechanism for the progression of malignancy was suggested wherein a vascular-like structure derived from tumor cells integrates with the host's endothelial system. The study of Maniotis et al. (9) in highly aggressive and genetically dysregulated melanoma cells, was the first to describe this novel and fascinating phenomenon that the authors termed as, "vasculogenic mimicry" (VM). $\mathrm{VM}$ is considered as a structure that can mimic vascular networks and has been equated to angiogenesis (10). VM has since been detected in several different types of cancers, such as head and neck, breast and prostate cancer $(9,11,12)$. Folkman et al. showed that existence of tumor cells in the lining of vessels could significantly promote cancer metastasis (13) and that the phenomenon correlates positively with poor prognosis of patients $(14,15)$. The high plasticity of cancer cells forming VM highlights the existence of a dedifferentiation process in cancer cells. Cancer stem cells (CSCs) are able to undergo dedifferentiation and have received substantive research focus (16). CSCs may represent causal factors in cancer recurrence, providing an alternative paradigm to cancer therapy.

Accordingly, recent findings highlight the possibility that CSCs or tumor-initiating cells in certain cancer types could be linked to resistance against conventional chemotherapy (17). These cells exhibit unique properties such as selfrenewal and differentiation into diverse cell types that constitute the tumor (18). CSCs in tumor cell lines share similar markers as those of their corresponding counterparts in original primary tumors (19). CSCs were identified based on their enriched expression of the cell surface markers CD44, CD133, ITGA2B1, KRT5/KRT14, KRT8/KRT18 and ABCG2 (20-22). In addition, genes used to score for "stemness", such as Oct4, Sox2, Nes and Nanog, could be markers for the identification of $\operatorname{CSCs}(23,24)$. It is noteworthy that in prostate cancer more than one stem cell type can be present (25). CSCs markers might also represent a valuable tool in the detection of primary cancer cells in micrometastasis. Proteins MMP2 and MMP9 play a pivotal role in tumor initiation, development, metastasis and neovascularization/angiogenesis $(6,26,27)$. However, the relationship between MMP2 and MMP9 levels and the presence of CSC markers (such as CD44 and CD133) is poorly defined and warrants further study (22).

Flavonoids are natural antioxidants and are almost ubiquitous in their distribution in the plant kingdom, particularly in most edible plants and medicinal herbs (28, 29). They are integral constituents of the human diet (28) and their dietary intake could be significant in vegetarian populations. Flavonoids are able to disrupt cellular and molecular events associated with tumor growth and metastasis. Substantial evidence indicates that certain dietary flavonoids, like luteolin and quercetin, can inhibit the growth and proliferation of tumor cells (30) and inhibit angiogenesis $(31,32)$. Luteolin ( $\mathrm{Lu})$ and quercetin $(\mathrm{Qu})$ can suppress metastasis of A431 cells by attenuating the Akt/mTOR/cMyc signaling pathway leading to a decreased expression of the ribosomal protein S12 (RPS12) (33). Furthermore, reversed epithelial-mesenchymal transition (EMT) to reduce MMP secretion by $\mathrm{Lu}$ and $\mathrm{Qu}$ exert inhibition of migration and invasion abilities in A431 cells (34). Since MMPs' function is central in tumor development, $\mathrm{Lu}$ and $\mathrm{Qu}$ inhibitory activity can potentially mitigate tumor progression, invasion, metastasis and tumor-associated angiogenesis $(3,4,7)$. $\mathrm{Lu}$ and $\mathrm{Qu}$ can also attenuate the phosphorylation of SRC and CTTN in A431-III cells, resulting in suppression of MMP secretion and impairment of invadopodia that are associated with degradation of the extracellular matrix in cancer invasiveness and metastasis (35). Since tumor growth and metastasis are dependent on angiogenesis, cancer therapeutic strategies have increasingly focused on targeting different aspects of angiogenesis. Previous reports have drawn attention to the ability of dietary flavonoids to attenuate angiogenic stimulants $(36,37)$.

Recent findings indicate that CSCs characterized by uncontrolled self-renewal can produce progeny cancer cells, which may explain cancer relapses and represent a critical target for cancer prevention. Zhang and coworkers established that genistein, a dietary isoflavonoid may inhibit the stemness of prostate cancer cells via the Sonic Hedgehog (SHH)-GLI1 pathway (38). The anthocyanin-containing baked purple-fleshed potato (PP) extracts (PA) may contribute to colon CSCs reduction and decrease the rate of tumor incidence in vivo by suppression of the Wnt/ $\beta$-catenin signaling pathway and increase of mitochondria-mediated apoptosis (39). Quercetin treatment reduced pluripotency, migration and adhesion of human teratocarcinoma cell line (40). Epigallocatechin-3-gallate (EGCG), accompanied by $\mathrm{Qu}$ treatment, was shown to inhibit prostate cancer stem cell characteristics and invasion (41). In these cells, EGCG was shown to regulate the $\mathrm{SSH}$ pathway and Nanog transcription factor of pluripotency (42). However, efforts to evaluate the 
efficacy of the above bioactive compounds on CSCs and decipher their potential effects in cancer are scanty. Towards this aim, CSCs were identified in Du145 prostate cancer cells and the relationship between CSCs and metastasis was characterized. Additionally, by using the above cell line model, the impact of $\mathrm{Lu}$ and $\mathrm{Qu}$ treatment on CSCs on cancer metastatis and progression was assessed.

\section{Materials and Methods}

Reagents. Quercetin was purchased from Nacalai Tesque (Kyoto, Japan). Luteolin was purchased from Extrasynthese (Genay, France). RPMI-1640 and fetal calf serum (FBS) were obtained from GIBCO (Grand Island, NY, USA). MMP9, Nanog and non-specific siRNAs were purchased from Invitrogen (Carlsbad, CA, USA). Anti- $\beta$-actin antibody was obtained from Sigma (St. Louis, MO, USA). Anti-CD44 and anti-ABCG2 antibodies were procured from Santa Cruz (Santa Cruz, CA, USA). Anti-Nanog, JNK, pJNK and Jun antibodies were acquired from Cell Signaling (Danvers, MA, USA). Anti-JUN antibody was obtained from Abcam (Cambridge, MA, USA). Forward and reverse PCR primers were purchased from Purigo Biotech (Taipei, Taiwan). Growth factor-reduced EHS matrigel was acquired from BD (Franklin Lake, NJ, USA). Enhanced chemiluminescence reagent (ECL) was obtained from Amersham (Buckinghamshire, UK). SP600125 was acquired from Merck (Whitehouse Station, NJ, USA).

Cell culture. The Du145 tumor cell line was obtained from ATCC. The cells were cultured as monolayer in an atmosphere of $5 \% \mathrm{CO}_{2}$ at $37^{\circ} \mathrm{C}$ and grown in tissue-culture flasks containing RPMI-1640 supplemented with $10 \%$ FBS.

In vitro invasion assay and isolation of highly invasive Du145 tumor cells. In vitro invasiveness was studied as previously described (43). Briefly, 24-well transwell units with polycarbonate filters $(8-\mu \mathrm{m}$ pore size; BD) were coated with $0.1 \mathrm{~mL}$ of $0.8 \mathrm{mg} / \mathrm{mL}$ EnglebrethHolm-Swarm (EHS) sarcoma tumor extract (BD) for $1 \mathrm{~h}$ at $25^{\circ} \mathrm{C}$. These filters were then air-dried at room temperature to form a thin and continuous layer on the filter surface. The lower compartment contained RPMI-1640 medium with $10 \%$ FBS as a chemoattractant Du145-P cells $\left(5 \times 10^{4}\right)$ were placed in the upper compartment and incubated with or without flavonoids at $37^{\circ} \mathrm{C}$ for $48 \mathrm{~h}$. Following incubation, the filters were fixed with $3 \%$ glutaraldehyde in PBS and stained with crystal violet. Cells on the upper surface of the filter were removed by wiping with a cotton swab; penetrating cells through the matrigel were counted using a microscope $(200 x)$. Two independent experiments were performed and each treatment was performed in triplicate.

To obtain cells with higher invasion capacity, the small inserts were removed, and the cells that settled onto the culture flask were continuously cultured until they reached $60 \%$ confluence. The cells were then sub-cultured (designated as Du145-I). The Du145-I cells were reapplied to the Boyden chamber, and the experiments described above were repeated until Du145-III cells were obtained (43).

Preparation of cell lysates. Lu and Qu treated and untreated Du145$\mathrm{P}$ and Du145-III cells were harvested and washed three times with PBS and lysed in Gold lysis buffer as previously described (44).
The insoluble material was collected by centrifugation at $14,000 \mathrm{xg}$ for $20 \mathrm{~min}$ at $4^{\circ} \mathrm{C}$.

Detection and characterization of MMPs. MMPs secreted from tumor cells were characterized using gelatin zymography (45). Samples from conditioned media were subjected to electrophoresis on $8 \%$ SDS-polyacrylamide gel (SDS-PAGE) containing $0.1 \%$ porcine gelatin. The volume of each sample analyzed was normalized by its corresponding cell number. After electrophoresis, the gels were washed twice for 30 min with $2.5 \%$ Triton X-100 and then twice with reaction buffer $(50 \mathrm{mM}$ Tris- $\mathrm{HCl}, \mathrm{pH} 8.0$, containing $5 \mathrm{mM} \mathrm{CaCl} 2,0.02 \% \mathrm{NaN}_{3}$ ) for $30 \mathrm{~min}$. The gels were then incubated in reaction buffer at $37^{\circ} \mathrm{C}$ for $48 \mathrm{~h}$.

In vitro wound-healing assay. Du145-P and Du145-III cells were plated onto six-well culture plates in RPMI-1640 containing $10 \%$ FBS $\left(2 \times 10^{6}\right.$ cells/well). After $24 \mathrm{~h}$, the cell layer was wounded by manual scratching with a pipette tip, washed with PBS and then incubated at $37^{\circ} \mathrm{C}$ with or without $20 \mu \mathrm{M} \mathrm{Lu}$ or Qu. The cells were photographed at 0 and $24 \mathrm{~h}$ after wounding using phase contrast microscopy and an Olympus IX70 camera.

In vitro capillary formation assay. $80 \mu \mathrm{L}$ of EHS matrigel was added to each well of a 48-well plate and allowed to solidify for $3 \mathrm{~h}$ at $37^{\circ} \mathrm{C}$. Following matrigel solidification, Du145-P and Du145III cells $\left(1.5 \times 10^{4}\right)$ were added to each well in serum-free medium. Four hours later, when the cells had adhered to the matrigel, Lu or $\mathrm{Qu}$ was added. The cells were incubated for $24 \mathrm{~h}$ at $37^{\circ} \mathrm{C}$. The capillary formation of Du145-P and Du145-III cells was detected by photography.

Western blot. The cell lysate samples were dissolved in $5 \times$ sample buffer, boiled for $5 \mathrm{~min}$ and then separated in 10\% SDS-PAGE gels. The nitrocellulose membranes used to transfer the proteins, were blocked in PBS containing 5\% BSA for $1 \mathrm{~h}$ at room temperature. The membrane blots were then incubated with primary antibody overnight at $4^{\circ} \mathrm{C}$, washed with TBST (Tris-buffered saline with Tween-20) as previously described (44) and then incubated with secondary antibody conjugated with horseradish peroxidase. The membranes were again washed with TBST and the immunoreactive protein bands were detected using ECL reagents exposed on Fujifilm. The relative signal intensity of ECL signals on X-ray film was quantified by Image $\mathbf{J}$ software analysis (NIH).

PCR amplification. Total RNA was isolated using the PureLink RNA Mini Kit (Invitrogen) and was reverse transcribed by the MMLV High Performance Reverse Transcriptase kit (Epicentre, Madison, WI, USA). The PCR program was performed for 20-40 cycles by denaturing at $94^{\circ} \mathrm{C}$ for $30 \mathrm{~s}$, annealing at $55-60^{\circ} \mathrm{C}$ for $30 \mathrm{~s}$, and extension at $72^{\circ} \mathrm{C}$ for $30-60 \mathrm{~s}$. The annealing temperature, extension time and reaction cycles were adjusted for different genes. The PCR products were separated on $2 \%$ agarose gels stained with SYBR safe DNA stain (Invitrogen) and visualized by UV exposure.

Transfection of siRNA. Du145-P and Du145-III cells $\left(2.5 \times 10^{5}\right.$ cells) were allowed to adhere in $60-\mathrm{mm}$ culture dishes for $24 \mathrm{~h}$. In order to prepare the transfection mixture, $6 \mathrm{uL}$ of Lipofectamine 2000 reagent (Invitrogen) was thoroughly mixed with $300 \mu \mathrm{L}$ serum-free RPMI-1640 medium and incubated for $5 \mathrm{~min}$ at room temperature. Then, $6 \mu \mathrm{L}$ of siRNA was added to $300 \mu \mathrm{L}$ serum- 
free RPMI-1640 medium and thoroughly mixed. The siRNA mixture was then combined with the diluted Lipofectamine 2000, gently mixed and incubated for $20 \mathrm{~min}$ at room temperature. The complexes were then added to the $60 \mathrm{~mm}$ culture dishes containing $2.4 \mathrm{~mL}$ serum-free RPMI-1640 medium for $24 \mathrm{~h}$. All assays were performed $48 \mathrm{~h}$ after transfection.

Spheroid assay. Du145-P and Du145-III cells were suspended in serum-free DMEM/F12 media supplemented with $0.2 \times$ B27 lacking Vitamin A (Invitrogen), EGF at $10 \mathrm{ng} / \mathrm{mL}, 1 \times$ antibiotics and antimycotic (GIBCO). The cells were then plated in 24-well ultralow-attachment plates (Corning) at a density of $4 \times 10^{3}$ cells/well. After two weeks, the plates were analyzed for tumor- sphere formation and quantified using an inverted microscope.

Statistical analysis. Statistical significance between groups was determined using an unpaired Student's $t$-test. A $p<0.05$ was considered significant for all tests. The results from three to six independent experiments are expressed as the mean \pm SEM.

\section{Results}

Isolation of Du145-III from Du145 prostate cancer cells. Although CSCs in prostate tumors have been previously detected, the relationship between stemness and malignancy of these cells has not been clearly shown. We speculated that a small population of stem-like cells in Du145 might overexpress MMPs and show metastatic potential. To investigate this possibility, we isolated a highly invasive prostate cancer subline (Du145-III) from the parental Du145$\mathrm{P}$ tumor cell line by three successive passages through a Boyden chamber with EHS matrigel-coated membrane support. After three rounds of selection, we observed that Du145-I, Du145-II and Du145-III expressed higher mRNA and secreted successively greater quantities of MMP9 than Du145-P (Figure 1A). We also observed that cell-to-cell adhesion of Du145-III cells decreased and dispersal of Du145-III cells increased compared to Du145-P cells. Additionally, Du145-III cells showed a tendency to have protruding filopodia, while Du145-P cells grew more cohesively (Figure 1B).

To probe the differences in cell migratory capacity and invasiveness between Du145-P and Du145-I, -II and -III cells, we performed in vitro wound-healing and invasion assays respectively. The results showed significant differences in the ability of Du145-P cells to migrate to the open area at $24 \mathrm{~h}$ compared to that of Du145-III cells. We found that Du145-III cells nearly closed the gap (Figure 1C) and the invasive ability exhibited by them was greater than that of Du145-P cells (Figure 1D).

Du145-III cells exhibit vasculogenic mimicry and intermix into the HUVEC network. Du145-III cells were found to secrete increased quantities of MMP9, compared to Du145-P cells (Figure 1A). Since MMP9 expression is related to angiogenesis, an in vitro capillary formation assay was employed in order to examine whether cells with increased MMP9 expression exhibit VM characteristics. This method has been previously used to study vessel formation by endothelial cells and to gauge the angiogenic capacity of tumor cells. Du145-P and sublines when cultured on matrigel, organize into tubular networks resembling capillaries. However, the extent of capillary formation showed a gradual increase from parental Du145 cells to sublines Du145-I, -II and -III (Figure 2A).

Formation of VM could be exhibited by stem-like cells that can differentiate and function as endothelial cells. To confirm that Du145-III cells can mimic an endothelial cell phenotype, HUVEC and Du145-III cells were cultured simultaneously in matrigel. Du145-III and HUVEC cells were transfected with double-strand RNA (dsRNA) conjugated with FITC or Alexa Fluor ${ }^{\circledR}$ Red respectively. As shown in Figure 2B, Du145-III and HUVEC cells adhered together and formed a network. To ascertain that Du145-III subline contains cells with an endothelial phenotype, we stained Du145-III in matrigel with isolectin B4 (IB4), which is a dye specific for endothelial cells. The results show that a network of capillaries was stained by IB4 (Figure 2C) and indicates that Du145-III might differentiate into or resemble endothelial cells.

Du145-III cells show increased self-renewal ability and expression of CSC markers compared to Du145-P cells. We examined whether Du145-III cells exhibited stem cell-like properties. Du145-P and Du145-III cells were plated in stem cell culture medium in ultra-low binding 24-well plates at a density of $4 \times 10^{3}$ cells/well. Both Du145-P and Du145-III cells were able to generate non-adherent spheroids separated from each other. Figure 3A shows anchorage-independent spheroids formed by Du145-P and Du145-III cells within 14 days culture. Du145-III cells formed larger spheroids and in greater numbers compared to Du145-P cells, suggesting that Du145-III cells possess higher quantities of stem-like cells than Du145-P cells.

It is well-known that CSCs express pluripotent markers, such as Nanog, Oct4 and Sox 2 and progenitor markers, such as CD44, CD133, KRT18 and ABCG2. The expression of these markers in Du145-III cells was analyzed and compared to the corresponding levels in Du145-P cells. Our results showed that Du145-III subline contain more stem-like cells, since it expressed more protein levels of CD44, ABCG2, Sox 2 and Nanog markers compared to the Du145-P cells (Figure 3B). There were no significant differences between the parental and subline cells regarding the levels of KRT18, Oct 4 and Sox 9 protein markers while CD133 marker was not detected at the protein level.

MMP9 is involved in the self-renewal and VM in Du145-III cells. MMPs play crucial roles in both tumor angiogenesis and 
A
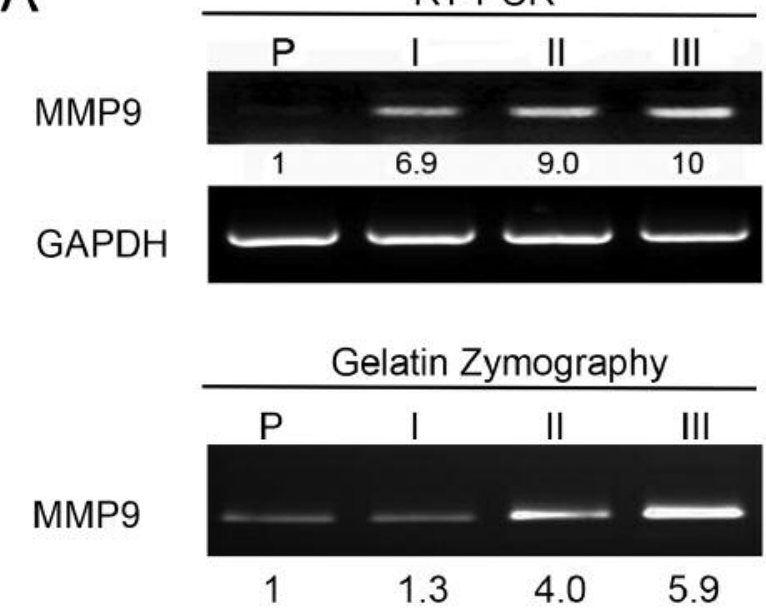

B

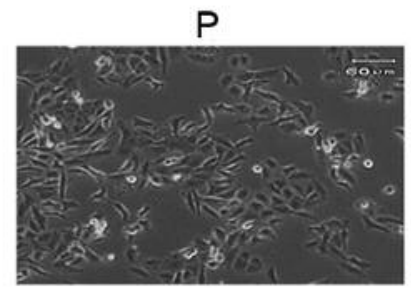

II

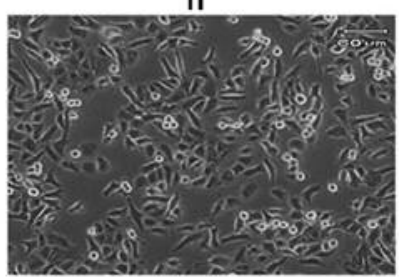

I

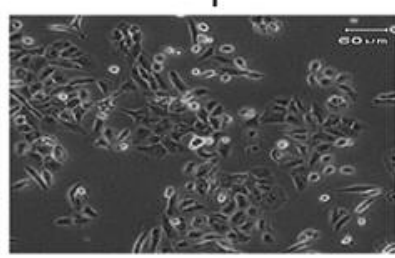

III

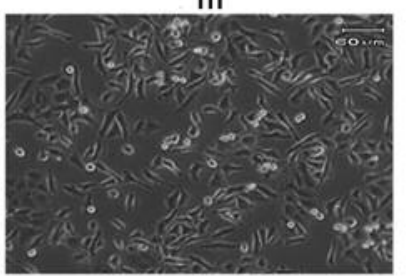

C

$\mathrm{P}$

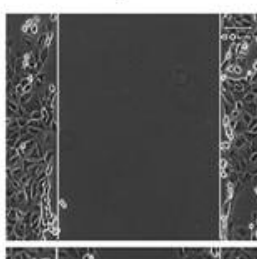

$24 \mathrm{~h}$

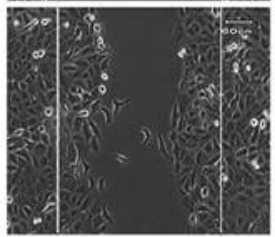

I

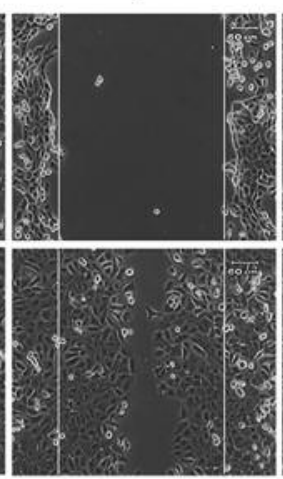

II

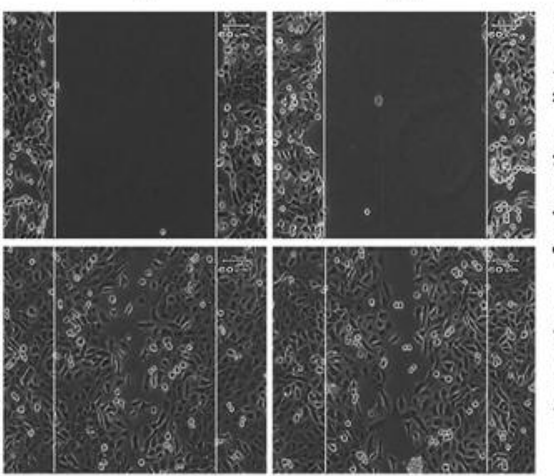

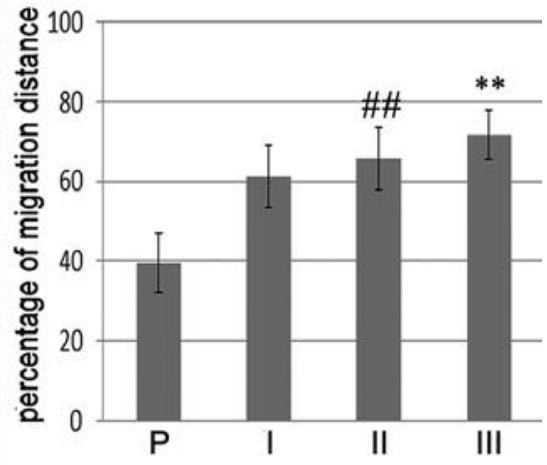

D

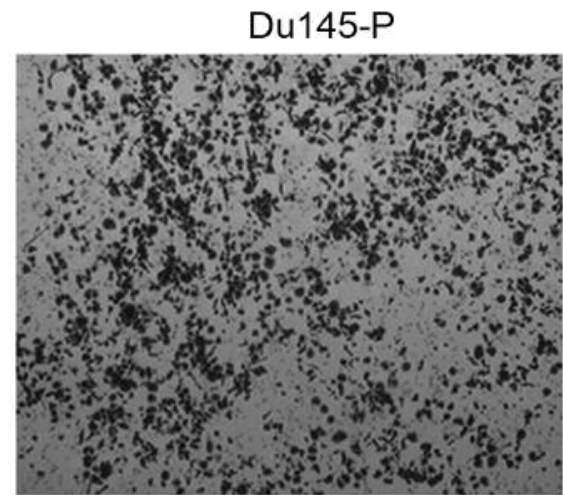

Du145-P

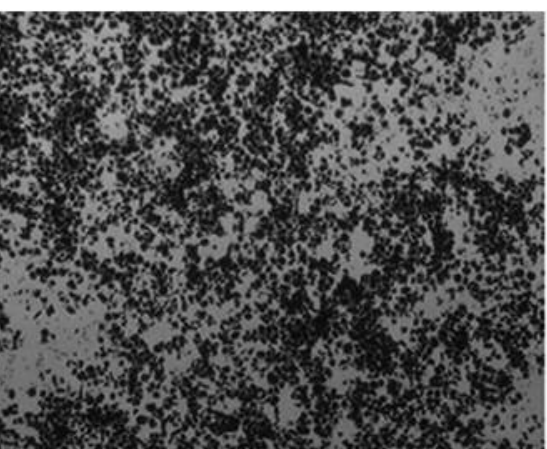

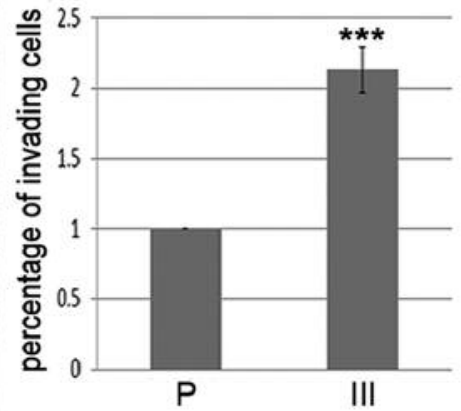

Figure 1. Du145 sublines exhibit higher MMP9 expression, secretion, cell scattering and motility compared to Du145-P. (A) Expression of MMP9 was analyzed by RT-PCR, and GAPDH served as an internal control. Conditioned media were collected and analyzed for MMP 9 activity using gelatin zymography. (B) Pattern of Du145-P, Du145-I, Du145-II and Du145-III subline spreading on culture plates. Du145-III grew more dispersed compared to that of Du145-P. (C) Migratory activity of Du145 sublines. Du145-III cells migrated faster than Du145-P did in in vitro wound-healing assays. Quantitative data from the wound-healing assay are presented as the mean $( \pm S D)$ percentage of migratory distance $(n=3)$. (D) Invasive pattern in Du145-P and Du145-III cells was analyzed by in vitro invasion assay. Du145-III cells exhibited higher invasiveness in comparison with that of Du145-P cells. Quantitative data from the invasion assay are presented as mean $( \pm S D)$ percentage of invaded cell number relative to the control value $(n=3) .{ }^{* *}{ }^{\# \#} p<0.01 ; * * * p<0.001 ; p$-Values were calculated using Du145-P cells as reference. The error bars represent the standard error of the mean. 
A
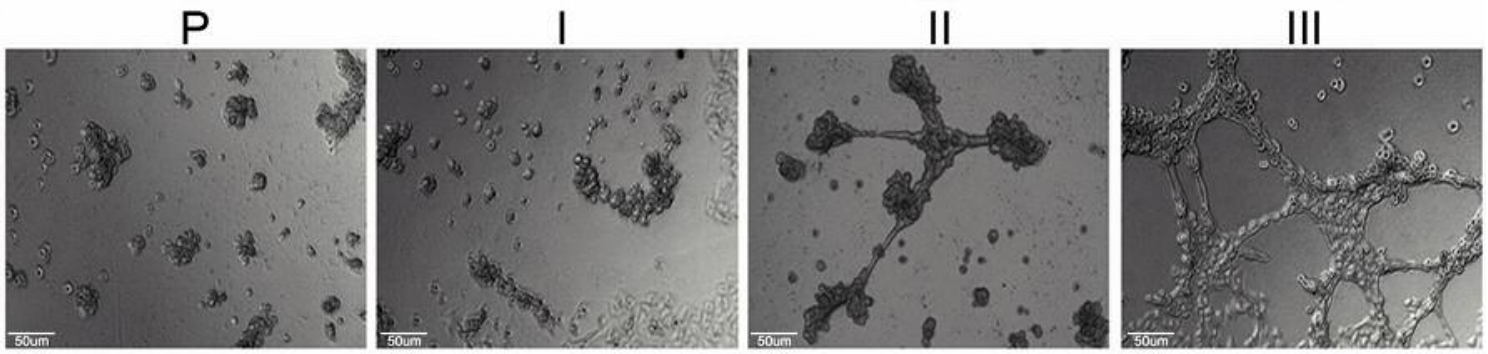

B
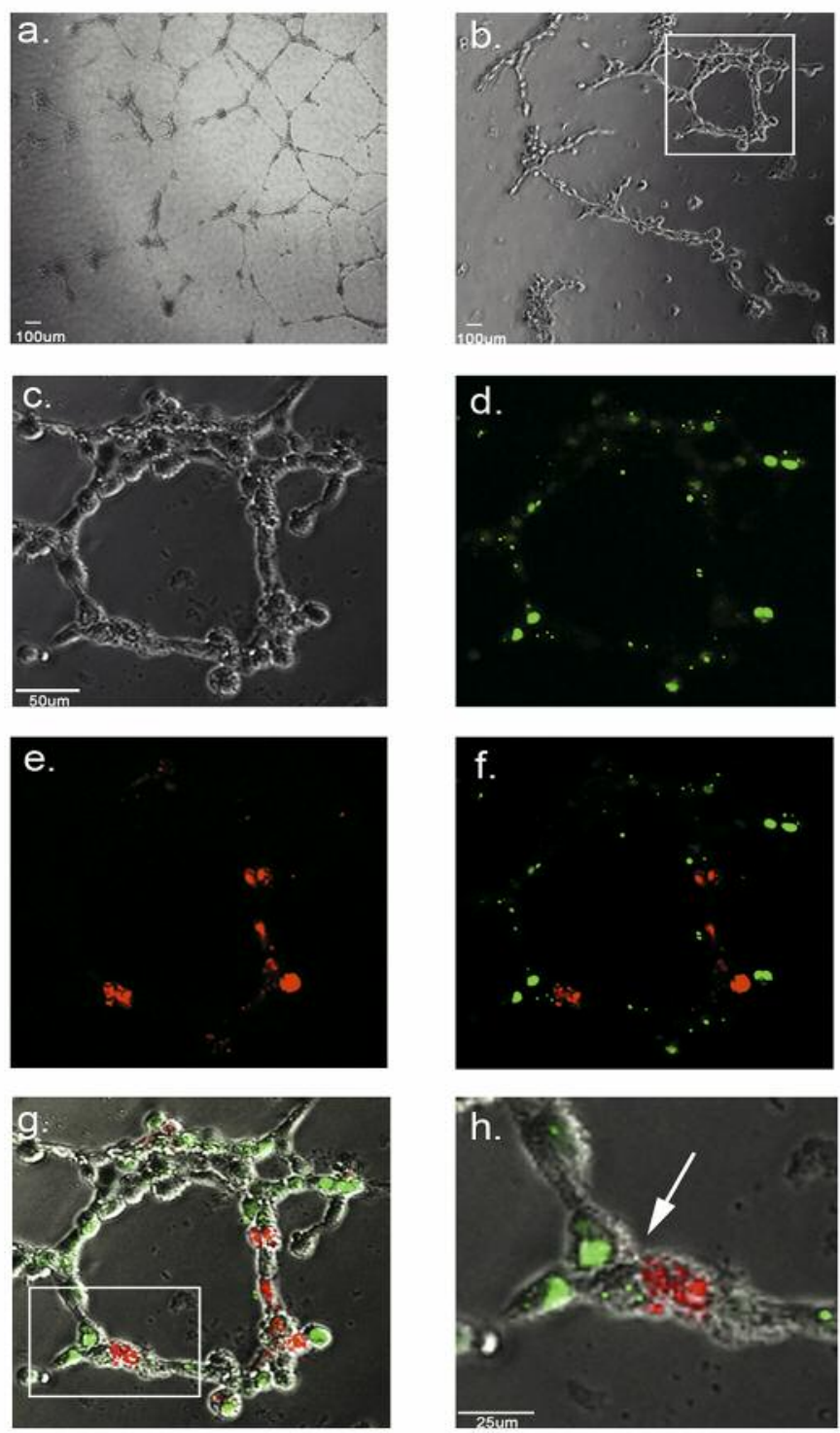

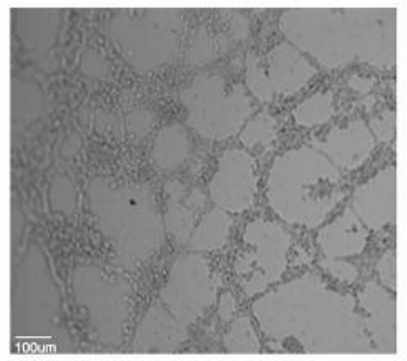

Bright field

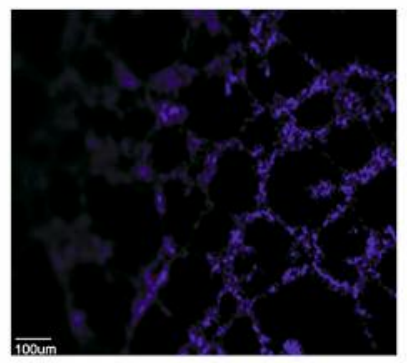

DAPI

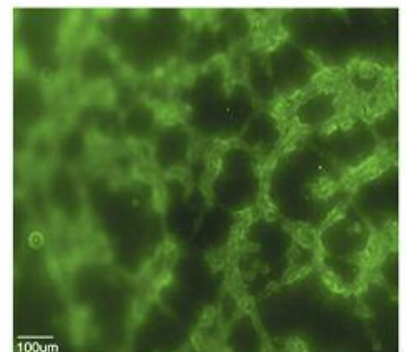

Isolectin B4

Figure 2. Du145-III subline exhibit vasculogenic mimicry and resembled endothelial phenotype. (A) Capillary-forming ability in Du145-P and Du145 sublines were analyzed by in vitro capillary formation assay. Du145-III cells formed mature capillary-like and network structures unlike the cell aggregates of Du145-P cells. (B) Co-culture of Du145-III cells and HUVEC in a 1:1 ratio. a, Only HUVEC were seeded on matrigel as a control. Panel b-h, Du145-III and HUVEC were both seeded in matrigel. Du145-III cells were transfected with dsRNA-FITC oligomer and were green. HUVEC were transfected with dsRNA-Alexa Fluor ${ }^{\circledR}$ Red Fluorescent oligomer and were red. Panel c-g is a magnification of the white rectangle in $b . h$ is the magnification of the white rectangle in panel $g .(C)$ The capillary-like and network structures in matrigel were stained with DAPI (blue) and isolectin B4 (green) to probe the existence of cell nuclei and endothelial cells. 


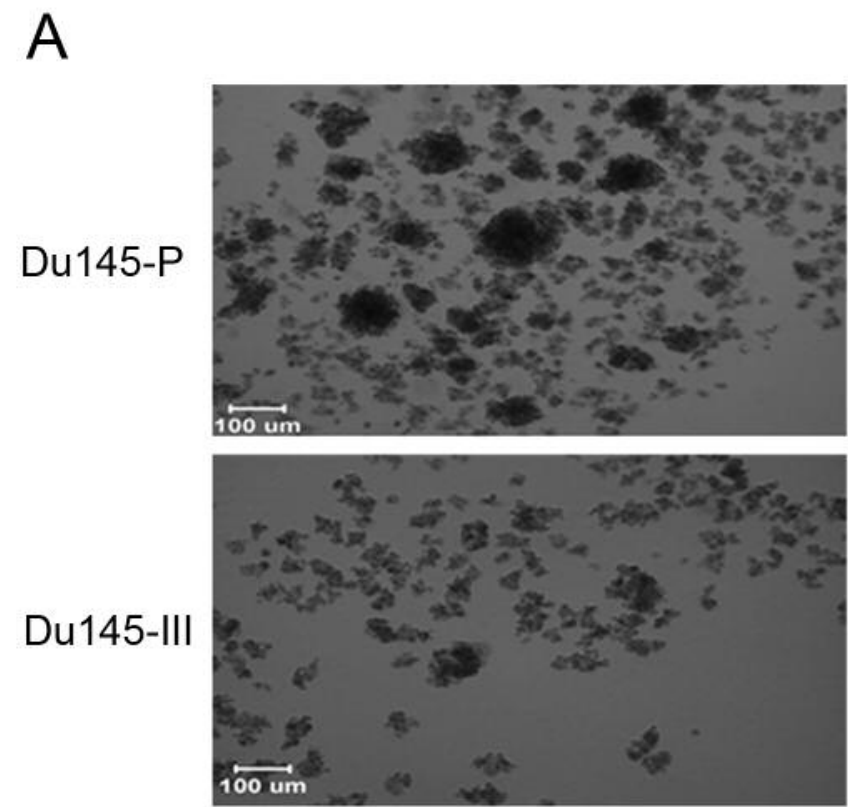

B

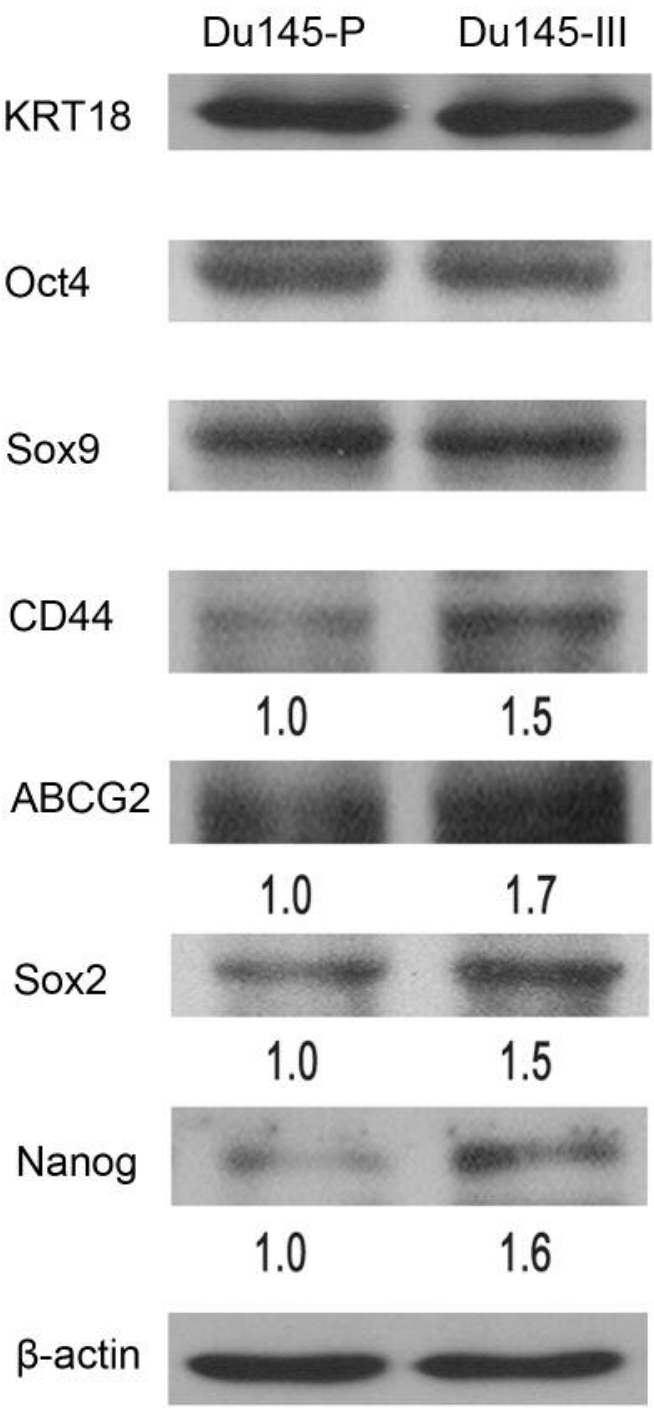

Figure 3. Du145-III cells show increased self-renewal capability and expression of CSC markers compared to Du145-P. (A) Dul45 cells were cultured in stem cell culture medium to promote spheroid formation. Upper panel: Representative photographs of spheroids from 14 day culture of Du145-P and Du145-III cells. Scale bar $=100 \mu \mathrm{m}$. Lower panel: the percentage of spheroids with diameter greater than $100 \mu \mathrm{m}$ was counted and quantitative data were presented as the mean $( \pm S D)$ percentage of spheroid number relative to the control value $(n=5)$. * $p>0.05 ; p$-Values were calculated using Du145-P cells as reference. Error bars represent the standard error of the mean. (B) Analysis of CSC markers in Du145-P and Du145-III cells via immunoblotting. $\beta$-actin was used as internal control.

vasculogenesis. Therefore, the potential role of MMP9 in VM was assessed by knocking-down MMP9 levels in Du145-III cells. Transfection of siRNA against MMP9 in Du145-III cells effectively reduced the levels of both mRNA and protein levels of MMP9 (Figure 4A). The inhibition of MMP9 reasonably inhibited both cell motility and invasiveness (Figure 4B and C). MMP9 siRNA-transfected Du145-III cells were also found to possess greatly attenuated capillary formation (Figure 4D). MMPs have been confirmed to be critical in maintaining stemness $(46,47)$. In this study, decreased MMP9 expression was found to greatly diminish the number and volume of spheroids in Du145-III cells (Figure 4E). These results indicate that MMP9 is necessary for the induction of VM and increased stemness in Du145-III cells. 
A
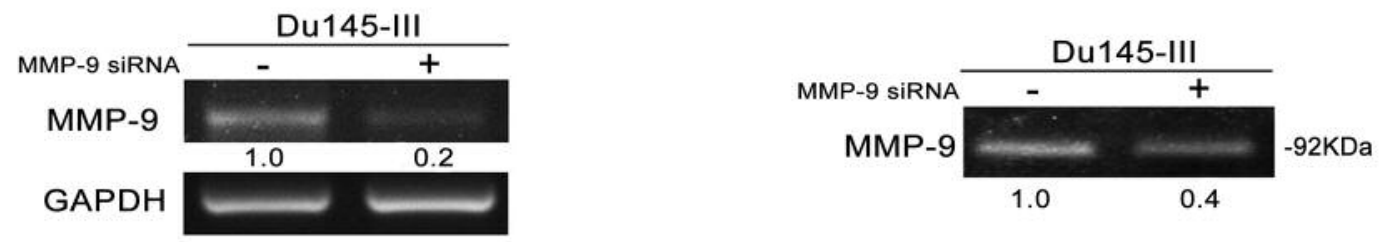

B
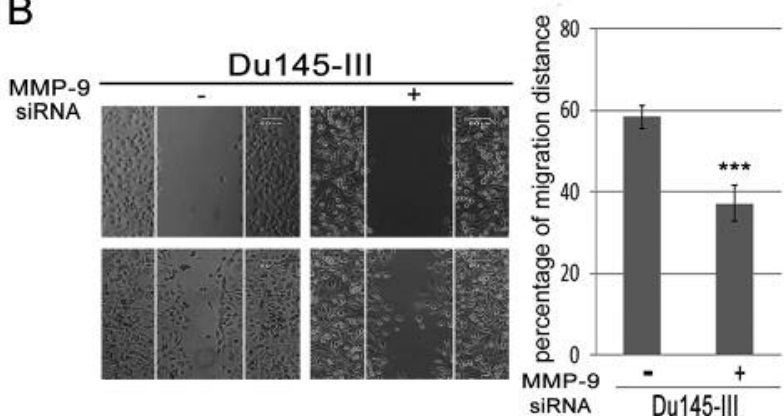

D

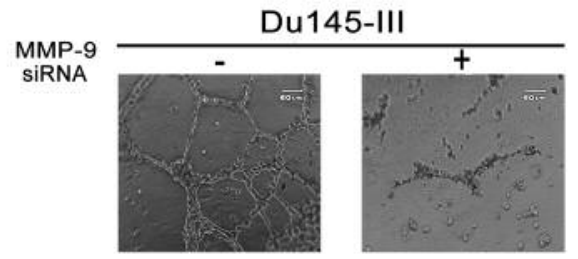

C
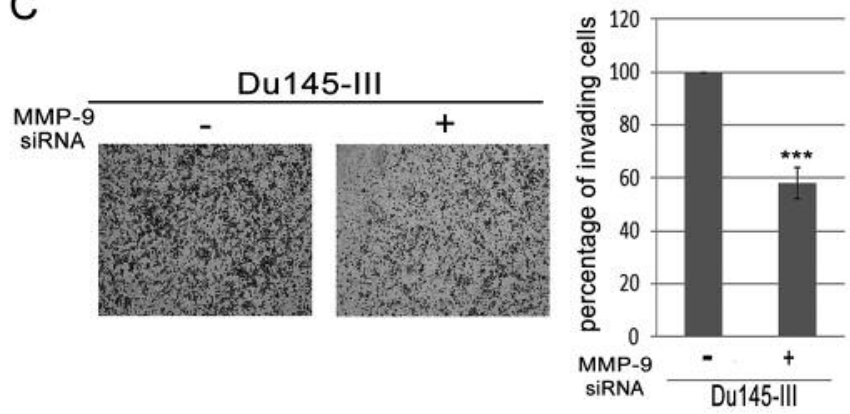

E
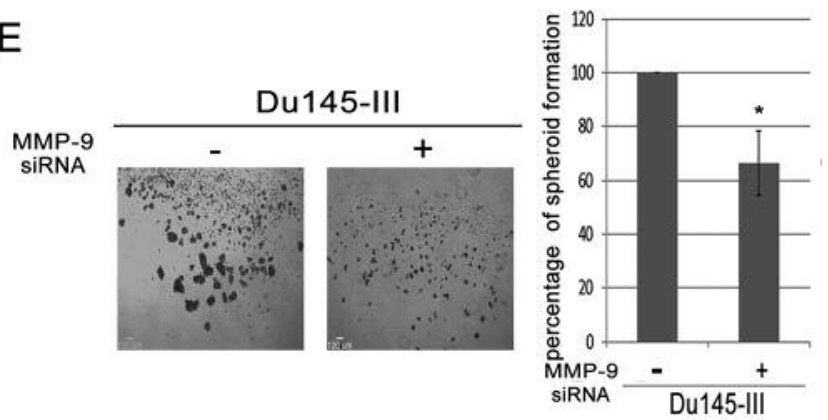

Figure 4. MMP9 regulates metastatic potential, self-renewal and vasculogenic mimicry in Du145-III cells. (A) Du145-III cells treated with 40 nM MMP9 siRNA effectively reduced the mRNA level and secretion of MMP9 as measured by RT-PCR and western blotting. (B) in vitro wound-healing and $(C)$ in vitro invasion assays following MMP9 siRNA transfection. Phase-contrast images were collected 24 h later to assess cell migration and invasiveness. Quantitative data of the in vitro wound-healing assay are presented as the mean ( $\pm S D)$ percentage of migration distance, ( $n=3)$. Quantitative data of the in vitro invasion assay are presented as the mean $( \pm S D)$ percentage of invaded cell number relative to control value ( $n=3)$. (D) MMP9 siRNA-transfected Du145-III cells were seeded in matrigel to assess MMP9 knockdown effect on capillary formation in vitro. (E) MMP9 siRNA-transfected Du145-III cells were seeded in stem cell culture medium for 14 days. Scale bar=100 $\mu$ m. The percentage of spheroids with diameter greater than $100 \mu \mathrm{m}$ is presented as the mean $( \pm S D)$ percentage of spheroid number relative to control value $(n=5)$. $* p<0.05 ; * * * p<0.001$; p-Values were calculated using Du145-P cells as reference. The error bars represent the standard error of the mean.

JNK signaling pathway is associated with the maintenance of stemness and metastatic potential in Du145-III cells. Recent studies have demonstrated that JNK plays a pivotal role in the maintenance of self-renewal and tumorigenicity $(48,49)$, governs stemness $(48,50)$ and is involved in the expression and secretion of MMP9 (51). Therefore, JNK phosphorylation activity might be required to maintain the stemness of Du145-III cells. Western blot analysis revealed that the levels of phosphorylated JNK and JUN protein in Du145-III cells are more than in Du145-P cells (Figure 5A). In order to associate the enhanced activity of JNK in Du145III cells with an increased metastatic potential or stemness,
Du145-III cells were treated with a JNK specific inhibitor (30 $\mu \mathrm{M}, \mathrm{SP600125}$ ). Inhibition of JNK activity led to a decrease of MMP9 secretion, cellular motility, and invasiveness in Du145-III cells (Figure 5B-D). Furthermore, SP600125 treatment disrupted capillary formation in Du145III cells (Figure 5E) and decreased the expression of CSC markers, Sox 2 and Nanog but did not change the expression of CD44 and ABCG2 markers compared to untreated cells (Figure 5F). Inhibition of JNK also reduced self-renewal ability and diminished sphere-forming capacity of Du145-III cells (Figure 5G). These results suggest that elevated JNK activity in Du145-III cells might associated with stemness. 
We then examined whether JNK could impair self-renewal capability by affecting pluripotent transcription factors. Nanog expression is reported to be regulated by Sox 2 and Oct4 (52). Thus, Nanog may be a downstream regulator of stemness. A Nanog-specific siRNA was used (Figure 5H) to knockdown Nanog in Du145-III which resulted in fewer and smaller spheroids, as shown in Figure 5I. Cumulatively, these data suggest that activation of JNK signaling pathway can increase motility and invasiveness in Du145-III cells via regulation of Nanog expression.

Luteolin and Quercetin inhibit VM, metastatic potential, and stemness via JNK activity in Du145-III cells. We next attempted to validate our hypothesis that $\mathrm{Lu}$ and $\mathrm{Qu}$ could inhibit JNK kinase activity and decrease MMP9 secretion, CSC marker expression and disrupt sphere-formation. A dramatic difference was found in the extent of MMP9 secretion between Du145-P and Du145-III cells. We have recently reported that A431-III cells shows high migratory ability of A431-III cells partly due to elevated expression of MMP9 and Snail, as evidenced by siRNA knockdown of these two genes (44). Therefore, the relatively higher levels of MMP9 secretion by Du145-III cells observed in the current study could lead to enhanced cell migration. We have previously established that out of $\mathrm{Lu}$ and $\mathrm{Qu}$ dietary flavonoids used in this study, are the two most active compounds against MMP secretion in cancer cells and therefore could interfere with tumor invasion, metastasis and VM stimulation.

In order to assess the effects of $\mathrm{Lu}$ or $\mathrm{Qu}$ treatment on metastasis and VM, Du145-III cells were treated with $20 \mu \mathrm{M}$ $\mathrm{Lu}$ or $\mathrm{Qu}$ for $24 \mathrm{~h}$ and MMP9 levels were analyzed by RTPCR and zymography. The expression and secretion of MMP9 were repressed by treatments with $\mathrm{Lu}$ or $\mathrm{Qu}$, as shown in Figure 6A. Interestingly, the flavonoid treated cells displayed a significant delay in Du145-III migration, depressed Du145-III invasion (Figure 6B) and significantly inhibited capillary formation, as shown in Figure 6C. Additionally, Du145-III cells treated with $20 \mu \mathrm{M} \mathrm{Lu}$ or $\mathrm{Qu}$ for $24 \mathrm{~h}$ showed markedly reduced expression of CD44, ABCG2, Sox 2 and Nanog compared to untreated cells (Figure 6D, left panel). Finally, the effect of $\mathrm{Lu}$ or $\mathrm{Qu}$ treatment on anchorage-independent spheroid formation was assessed in Du145-III cells. Treatment with $\mathrm{Lu}$ or $\mathrm{Qu}$ dramatically reduced the number and volume of spheroids in cultured Du145-III cells (Figure 6D, right panel).

The results obtained from our previous experiments revealed that JNK played a crucial role in the acquisition of stemness and metastatic potential in Du145-III cells and that $\mathrm{Lu}$ and $\mathrm{Qu}$ were also involved in the regulation of these capabilities in Du145-III cells. The results led us to speculate that $\mathrm{Lu}$ and $\mathrm{Qu}$ may regulate the JNK signaling pathway. As shown in Figure 6E, Lu and Qu inhibit phosphorylation of
JNK and JUN. However, the total protein levels of JNK and JUN were not altered. These data suggest that both Lu and $\mathrm{Qu}$ inhibit the metastatic potential, VM, and stemness of CSCs through via modulation of the JNK signaling pathway.

\section{Discussion}

Recent evidence links CSCs with cancer metastasis and relapse $(18,53)$. In order to explore the causal role of CSCs in metastasis, several CSC isolation methods have been developed (54). Yu and coworkers utilized the Boyden chamber apparatus to isolate potential CSCs based on their invasive properties. They showed that an invasive population within the U87 glioma cell line had high levels of CSCs (54). Additional evidence has shown the presence of CSCs in various human cancers (55-57). Prostate tumors have been reported to contain approximately $0.1 \%$ CSCs (58). In this study, a highly invasive prostate cancer Du145-III subline was isolated from its parental Du145-P cell line by three passages through the EHS matrigel-coated Boyden chamber apparatus. Du145-III cells were demonstrated to have increased levels of MMP9, enhanced cell migration and high levels of invasion compared to Du145-P, which prompted us to investigate VM in Du145-III cells.

In this study, VM was clearly observable in Du145-P and Du145 sublines by in vitro capillary formation assays but Du145-III cells however showed more complete capillaries and network structure formation. Interestingly, we identified a possible connection between VM and endothelial cells since Du145-III and HUVEC developed a network structure collectively. It is particularly noteworthy that staining with isolectin B4 of Du145-III cells revealed within the formedcapillaries the presence of endothelial cell subpopulations. Therefore, the structure and the expression of endothelial markers of these capillaries need to be characterized to gain insights into this finding in the further. Recent studies have proposed the involvement of CSCs in this differentiation process in prostate cancer cells (59). However, there is currently limited evidence supporting the functional importance of VM in prostate cancer. Confirmation along these lines is a key aim in the field of human prostate cancer research. Data accrued suggest that Du145-III cells may display a phenotype resembling endothelial cells via dedifferentiation and that VM might be mediated by CSCs (60).

The Du145-III subline exhibits increased expression of MMP9 and stem cell markers and enhanced capillary and spheroid formation. This prompted us to hypothesize that there is a positive regulatory loop between MMP9 and CSCs. We premise that MMP9 might play an important role in promoting VM and spheroid formation. Recent studies have demonstrated that the inhibition of JNK activity triggers the loss of self-renewal capability and reduces CSC markers such as Sox2, NES, and BMI1(49). In our system, we also 
A

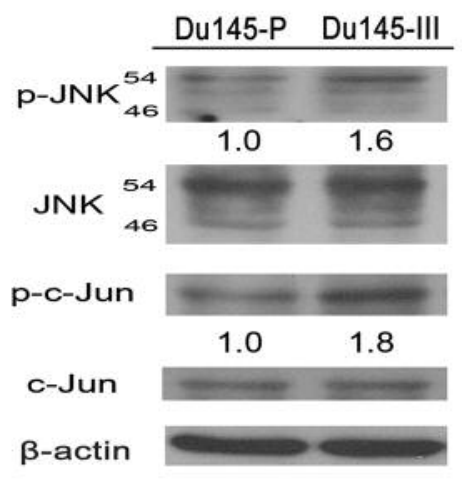

D

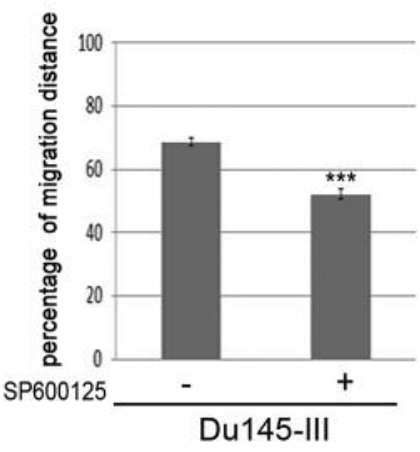

$\mathrm{F}$

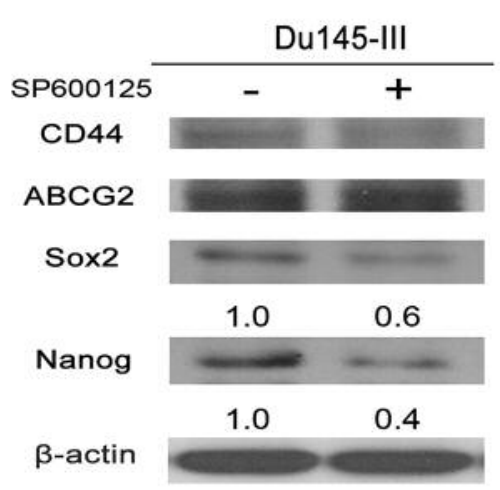

$\mathrm{H}$
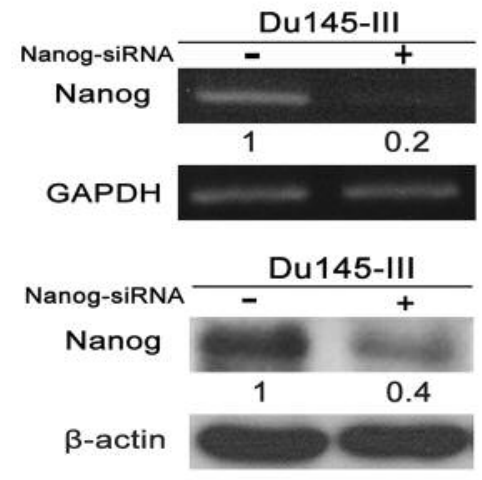

B

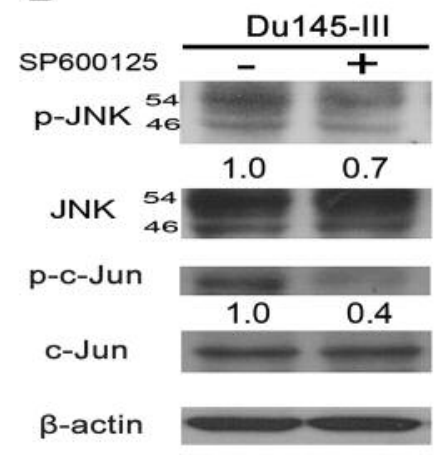

C

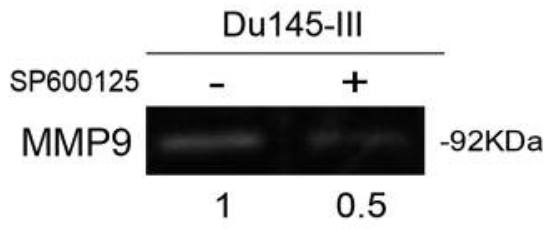

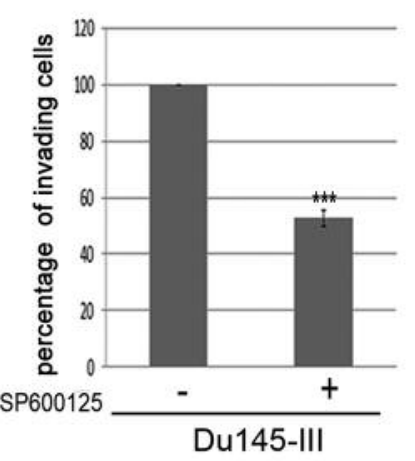

$E$

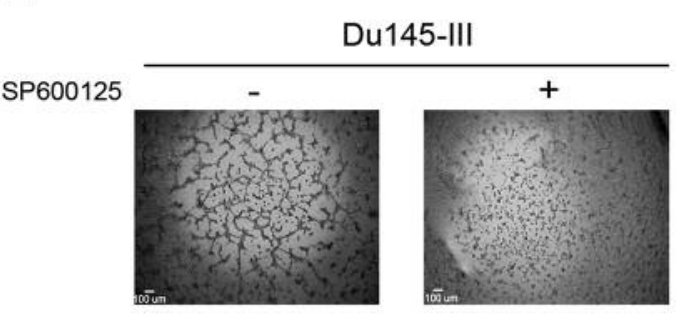

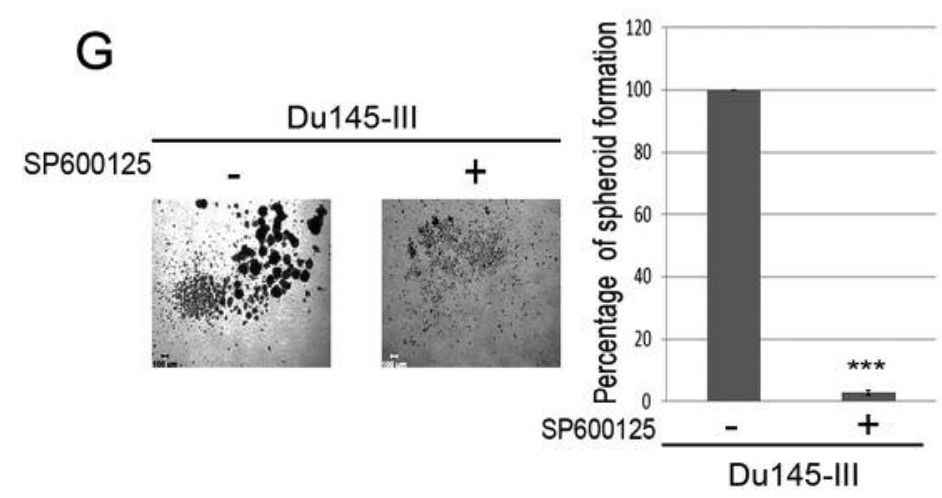
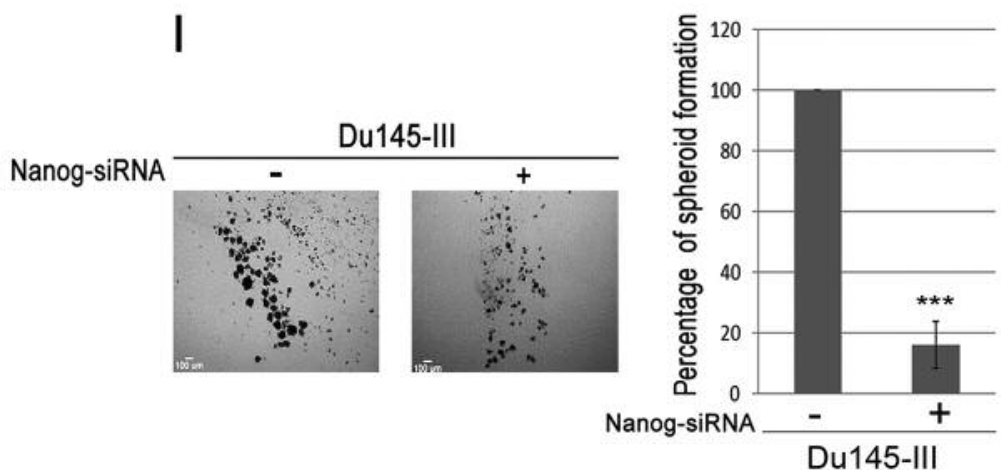
detected that JNK inhibition reduced Sox2 and Nanog expression and impaired self-renewal capacity. The impact of MMP9 on spheroid formation, as we have established above, is one of our most substantial and noteworthy findings. We also conjecture that Nanog expression decrement accounts for this observed reduction.

Indeed, the knockdown of Nanog could have synergized with the action of EGCG in impairing spheroid formation in CSCs (41). In our system, we found that the knockdown of Nanog reduced both spheroid number and volume. These data strongly indicated that the inactivation of JNK attenuated metastatic potential and stemness via regulation of MMP9 and suppressed the self-renewal capability of Du145-III via Nanog. A similar result caused by the knockdown of MMP9 and of Nanog might be a major finding that clarifies the interrelationship between CSCs and MMP9.

We have previously shown (28) that $\mathrm{Lu}$ and $\mathrm{Qu}$ are the two most potent flavonoid modulators of oncogenesis inhibition and that they exhibited a variety of anticancer effects, such as cell growth and kinase activity inhibition, apoptosis induction, differentiation, suppression of MMP expression, reduction in tumor cell adhesion, and impairment of cancer invasive behavior, metastasis and angiogenesis in a wide spectrum of tumor cells $(29,30,61,62)$. Additionally, we detected that the pharmacologic effects of $\mathrm{Lu}$ and $\mathrm{Qu}$ extended to other realms of anticancer activity, including the suppression and secretion of MMP9. Lu and Qu also suppressed the migratory and invasive potential and VM in Du145-III cells. These profound actions suggest that these two dietary flavonoids impair the metastatic potential and VM of Du145-III cells.

CSCs promote tumor onset and metastasis and are often resistant to conventional therapies. Therefore, we further explored the potential effects of plant flavonoids on the expression of diverse markers intricately linked with tumor formation and metastasis in CSCs from the Du145-III subline. We found that $\mathrm{Lu}$ and $\mathrm{Qu}$ lowered the expression of CSC markers CD44, ABCG2, Sox2 and Nanog and substantively attenuated cancer stem cell associated spheroid formation. Lu and Qu inhibited the JNK signaling pathway, which explains their effects on stemness, VM and metastatic potential. Previous studies have indicated that JNK kinase activity plays an important role in maintaining the stemness of glioblastoma and other cells $(48,49)$.

We may consider that one of the potentially successful approaches to the treatment and management of cancer would involve anticancer therapy that judiciously impairs differentiated cancer cell functions and significantly diminishes the CSC population (63). Our Du145-III cell model appears to be promising in that it establishes a rapid, sensitive and reliable method with the preamble of enriching and obtaining highly invasive cancer cells amenable for studying the relationship between CSCs and metastasis. A comparison of Du145-P and Du145-III cells provides a useful experimental strategy to characterize signaling pathways and genes that are relevant to the regulation of stemness, cell migration, and invasion. Our future studies will involve establishing animal models with subcutaneous or orthotopic implants of prostate cancer Du145-III cells, as previously described (64), to further comprehend the intricacies of the JNK signaling pathway in vivo. CSCs, not the remaining tumor cells, possess the capacity to initiate a tumor that resembles the heterogeneity and characteristics of the original tumor when transplanted in vivo (50). Using this animal model, we can identify candidate molecules involved in the JNK signaling pathway. In addition, we wish to learn whether Lu, Qu, and SP600125 suppress the JNK pathway in vivo.

\footnotetext{
$\leftarrow$

Figure 5. Du145-III cells exhibit higher metastasis potential and CSC characteristics via JNK pathway than Du145-P cells. (A) Total and phosphorylated protein levels of JNK and Jun determined using samples from Du145-P and Du145-III cells. $\beta$-Actin used as an internal control. (B) Total as well as phosphorylated protein levels of JNK and Jun determined following treatment of Du145-P and Du145-III cells with $30 \mu M$ SP600125. (C) Conditioned media were collected and analyzed for MMP9 activity using gelatin zymography following treatment with $30 \mu M$ SP600125. (D) In vitro wound-healing and in vitro invasion assays were conducted after treatment with $30 \mu M$ SP600125. Quantitative data of the wound-healing assay are presented as the mean $( \pm S D)$ percentage of migratory distance $(n=3)$. Quantitative data of the invasion assay are presented as the mean $( \pm S D)$ percentage of invaded cell number relative to the control value $(n=3)$. (E) Du145-III cells treated with $30 \mu M$ SP600125 were seeded in matrigel to assess how SP600125 may affect capillary formation in vitro. (F) Du145-III cell lysates were subjected to immunoblotting analysis of CSC markers. $\beta$-actin used as internal control. (G) Du145-III cells were assayed for spheroid formation after culturing them 14 days with $30 \mu M$ SP600125. Scale bar=100 $\mu m$. Percentage of spheroids with diameter greater than $100 \mu \mathrm{m}$ is shown. Quantitative data are presented as the mean $( \pm S D)$ percentage of spheroid number relative to the control value $(n=5)$. The error bars represent the standard error of the mean. (H) Du145-III cells were treated with $40 \mathrm{nM}$ Nanog or control siRNA for $48 \mathrm{~h}$. Total RNAs were isolated and analyzed by RT-PCR for Nanog mRNA levels. GAPDH was used as internal control. Total cell lysates were prepared and analyzed by immunoblotting for Nanog protein levels. $\beta$-actin was used as internal control. (I) Following Nanog siRNA transfection, Du145-III cells were assayed for spheroid formation at 14 days of culture. Scale bar $=100 \mu \mathrm{m}$. Percentage of spheroids with diameter greater than 100 $\mu m$ is shown. Quantitative data are presented as the mean $( \pm S D)$ percentage of spheroid number relative to control value $(n=5) . * * * p<0.001 . p$-Values were calculated using Du145-P cells as reference. The error bars represent the standard error of the mean.
} 
A

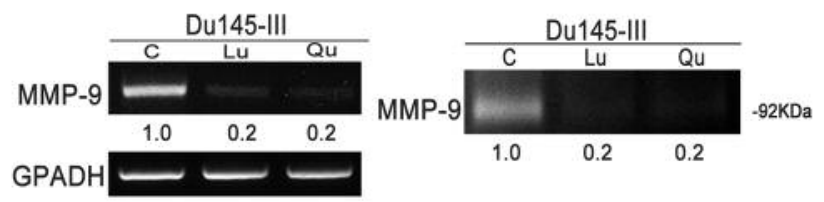

C

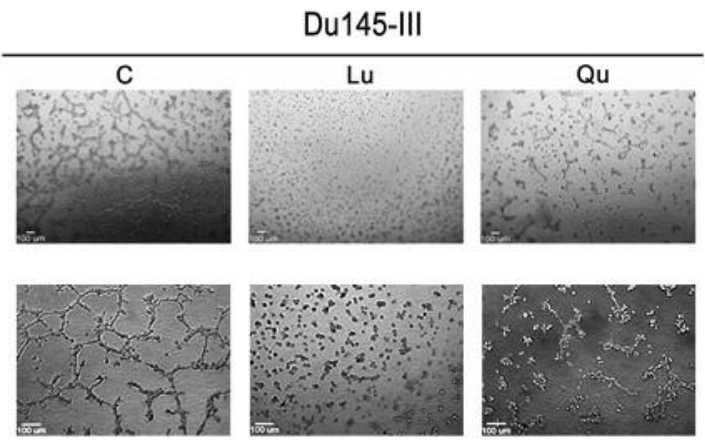

B
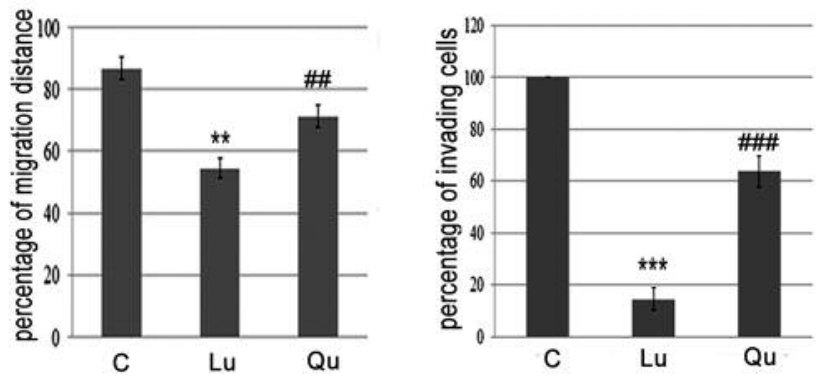

D

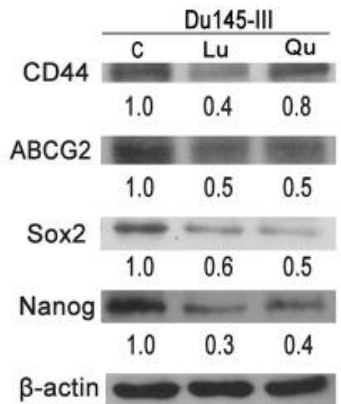

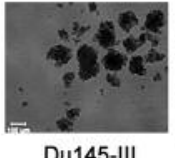

Du145-III

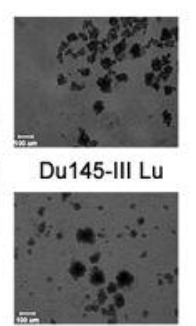

Du145-III Qu

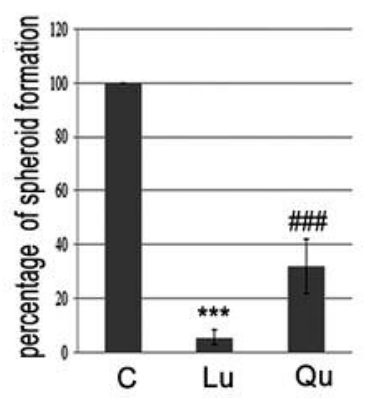

E

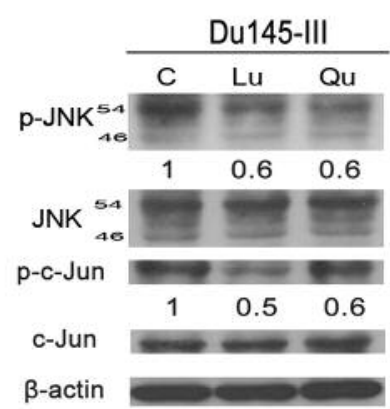

Figure 6. Luteolin and quercetin inhibit metastatic potential, VM formation and CSC characteristics via modulation of the JNK pathway activity. Cells were treated with $20 \mu \mathrm{M}$ Lu or Qu for $24 \mathrm{~h}$. (A) Expression of MMP9 analyzed by RT-PCR. GAPDH used as internal control. Samples from conditioned medium were collected and analyzed for MMP9 activity by gelatin zymography. (B) Migratory activity and invading activity of Du145III cells were analyzed by in vitro wound-healing and in vitro invasion assays. Quantitative data of the wound-healing assay are presented as the mean $( \pm S D)$ percentage of migratory distance $(n=3)$. Quantitative data of the invasion assay are presented as the mean $( \pm S D)$ percentage of invaded cell number relative to control value $(n=3)$. (C) Du145-III cells treated with Lu or Qu were seeded in matrigel to assess the effect on VM. (D) Analysis of CSC markers and self-renewal capability in Du145-III cells treated with either $20 \mu M$ Lu or Qu. (E) Phosphorylation of JNK and JUN was determined. $\beta$-Actin used as internal control. ${ }^{* *},{ }^{\# \#} p<0.01 ; * * *,{ }^{\# \#} p<0.001$. $p$-Values were calculated using Du145-P cells as reference. The error bars represent the standard error of the mean.

Our present data suggest that $\mathrm{Lu}$ and $\mathrm{Qu}$ are promising and prospective candidates that function as anti-CSC and antimetastasis agents. Together with the JNK inhibitor SP600125, they may provide a new approach for therapeutic treatment in the future. In addition, our selective Du145-III prostate cancer cell model system could serve as a useful tool to develop and establish effective therapies that target CSCs.

\section{Acknowledgements}

This work was supported in part by grants from the National Science Council of Taiwan (NSC 102-2311-B-002 -046 -MY3 to G.D.C.); Ministry of Science and Technology, Taiwan , R.O.C. (104-2311-B-038-001 to C.H.C.) and the Taiwan Academia Sinica Thematic Project (AS-96-TPB06 to M.T.L.) 


\section{References}

1 Jemal A, Bray F, Center MM, Ferlay J, Ward E and Forman D: Global cancer statistics. CA Cancer J Clin 61: 69-90, 2011.

2 Vihinen P, Ala-aho R and Kahari VM: Matrix metalloproteinases as therapeutic targets in cancer. Current Cancer Drug Targets 5: 203-220, 2005.

3 Westermarck $\mathrm{J}$ and Kahari VM: Regulation of matrix metalloproteinase expression in tumor invasion. FASEB $\mathrm{J} 13$ : 781-792, 1999.

4 Kessenbrock K, Plaks V and Werb Z: Matrix metalloproteinases: regulators of the tumor microenvironment. Cell 141: 52-67, 2010.

5 Littlepage LE, Sternlicht MD, Rougier N, Phillips J, Gallo E, Yu Y, Williams K, Brenot A, Gordon JI and Werb Z: Matrix metalloproteinases contribute distinct roles in neuroendocrine prostate carcinogenesis, metastasis, and angiogenesis progression. Cancer Res 70: 2224-2234, 2010.

6 Rundhaug JE: Matrix metalloproteinases, angiogenesis, and cancer: commentary re: A. C. Lockhart et al., Reduction of wound angiogenesis in patients treated with BMS-275291, a broad spectrum matrix metalloproteinase inhibitor. Clin. Cancer Res., 9: 00-00, 2003. Clin Cancer Res 9: 551-554, 2003.

7 Chetty C, Lakka SS, Bhoopathi P and Rao JS: MMP-2 alters VEGF expression via alphaVbeta3 integrin-mediated PI3K/AKT signaling in A549 lung cancer cells. Int J Cancer 127: 1081-1095, 2010.

8 Roy R, Yang J and Moses MA: Matrix metalloproteinases as novel biomarkers and potential therapeutic targets in human cancer. Journal of Clinical Oncology 27: 5287-5297, 2009.

9 Maniotis AJ, Folberg R, Hess A, Seftor EA, Gardner LM, Pe'er J, Trent JM, Meltzer PS and Hendrix MJ: Vascular channel formation by human melanoma cells in vivo and in vitro: vasculogenic mimicry. Am J Pathol 155: 739-752, 1999.

10 Karroum A, Mirshahi P, Faussat AM, Therwath A, Mirshahi M and Hatmi M: Tubular network formation by adriamycinresistant MCF-7 breast cancer cells is closely linked to MMP-9 and VEGFR-2/VEGFR-3 over-expressions. Eur J Pharmacol 685: $1-7,2012$.

11 Upile T, Jerjes W, Radhi H, Al-Khawalde M, Kafas P, Nouraei $\mathrm{S}$ and Sudhoff H: Vascular mimicry in cultured head and neck tumour cell lines. Head Neck Oncol 3: 55, 2011.

12 Zhang S, Zhang D and Sun B: Vasculogenic mimicry: current status and future prospects. Cancer Lett 254: 157-164, 2007.

13 Folkman J: Can mosaic tumor vessels facilitate molecular diagnosis of cancer? Proc Natl Acad Sci USA 98: 398-400, 2001

14 Folberg R, Arbieva Z, Moses J, Hayee A, Sandal T, Kadkol S, Lin AY, Valyi-Nagy K, Setty S, Leach L, Chevez-Barrios P, Larsen P, Majumdar D, Pe'er J and Maniotis AJ: Tumor cell plasticity in uveal melanoma: microenvironment directed dampening of the invasive and metastatic genotype and phenotype accompanies the generation of vasculogenic mimicry patterns. Am J Pathol 169: 1376-1389, 2006.

15 Sun B, Zhang S, Zhao X, Zhang W and Hao X: Vasculogenic mimicry is associated with poor survival in patients with mesothelial sarcomas and alveolar rhabdomyosarcomas. Int $\mathbf{J}$ Oncol 25: 1609-1614, 2004.

16 Yao XH, Ping YF and Bian XW: Contribution of cancer stem cells to tumor vasculogenic mimicry. Protein Cell 2: 266-272, 2011.

17 Prince ME, Sivanandan R, Kaczorowski A, Wolf GT, Kaplan MJ, Dalerba P, Weissman IL, Clarke MF and Ailles LE:
Identification of a subpopulation of cells with cancer stem cell properties in head and neck squamous cell carcinoma. Proc Natl Acad Sci USA 104: 973-978, 2007.

18 Visvader JE and Lindeman GJ: Cancer stem cells in solid tumours: accumulating evidence and unresolved questions. Nat Rev Cancer 8: 755-768, 2008.

19 Klarmann GJ, Hurt EM, Mathews LA, Zhang X, Duhagon MA, Mistree T, Thomas SB and Farrar WL: Invasive prostate cancer cells are tumor initiating cells that have a stem cell-like genomic signature. Clin Exp Metastasis 26: 433-446, 2009.

20 Collins AT, Habib FK, Maitland NJ and Neal DE: Identification and isolation of human prostate epithelial stem cells based on alpha(2)beta(1)-integrin expression. J Cell Sci 114: 3865-3872, 2001.

21 Richardson GD, Robson CN, Lang SH, Neal DE, Maitland NJ and Collins AT: CD133, a novel marker for human prostatic epithelial stem cells. J Cell Sci 117: 3539-3545, 2004.

22 Wicha MS, Liu S and Dontu G: Cancer stem cells: an old idea-a paradigm shift. Cancer Res 66: 1883-1890; discussion 18951886,2006

23 Nakagawa M, Koyanagi M, Tanabe K, Takahashi K, Ichisaka T, Aoi T, Okita K, Mochiduki Y, Takizawa N and Yamanaka S: Generation of induced pluripotent stem cells without Myc from mouse and human fibroblasts. Nat Biotechnol 26: 101-106, 2008.

24 Okita K, Nakagawa M, Hyenjong H, Ichisaka T and Yamanaka S: Generation of mouse induced pluripotent stem cells without viral vectors. Science 322: 949-953, 2008.

25 Pfeiffer MJ and Schalken JA: Stem cell characteristics in prostate cancer cell lines. Eur Urol 57: 246-254, 2010.

26 Bergers G, Brekken R, McMahon G, Vu TH, Itoh T, Tamaki K, Tanzawa K, Thorpe P, Itohara S, Werb Z and Hanahan D: Matrix metalloproteinase- 9 triggers the angiogenic switch during carcinogenesis. Nat Cell Biol 2: 737-744, 2000.

27 Rojiani MV, Alidina J, Esposito N and Rojiani AM: Expression of MMP-2 correlates with increased angiogenesis in CNS metastasis of lung carcinoma. Int J Clin Exp Pathol 3: 775-781, 2010.

28 Kandaswami C, Lee LT, Lee PP, Hwang JJ, Ke FC, Huang YT and Lee MT: The antitumor activities of flavonoids. In Vivo 19: 895-909, 2005.

29 Middleton E Jr., Kandaswami C and Theoharides TC: The effects of plant flavonoids on mammalian cells: implications for inflammation, heart disease, and cancer. Pharmacol Rev 52: 673$751,2000$.

30 Lee LT, Huang YT, Hwang JJ, Lee PP, Ke FC, Nair MP, Kanadaswam C and Lee MT: Blockade of the epidermal growth factor receptor tyrosine kinase activity by quercetin and luteolin leads to growth inhibition and apoptosis of pancreatic tumor cells. Anticancer Res 22: 1615-1627, 2002.

$31 \mathrm{Kim}$ MH: Flavonoids inhibit VEGF/bFGF-induced angiogenesis in vitro by inhibiting the matrix-degrading proteases. J Cell Biochem 89: 529-538, 2003.

32 Wu WB, Hung DK, Chang FW, Ong ET and Chen BH: Antiinflammatory and anti-angiogenic effects of flavonoids isolated from Lycium barbarum Linnaeus on human umbilical vein endothelial cells. Food Funct 3: 1068-1081, 2012.

33 Lin CW, Lai GM, Chen KC, Lin TH, Fan JJ, Hsu RL, Chou CM, Lin CM, Kandaswami CC, Lee MT and Cheng CH: RPS12 increases the invasiveness in cervical cancer activated by c-Myc and inhibited by the dietary flavonoids luteolin and quercetin. Journal of Functional Foods 19: 236-247, 2015. 
34 Lin YS, Tsai PH, Kandaswami CC, Cheng CH, Ke FC, Lee PP, Hwang JJ and Lee MT: Effects of dietary flavonoids, luteolin, and quercetin on the reversal of epithelial-mesenchymal transition in A431 epidermal cancer cells. Cancer Sci 102: 1829-1839, 2011.

35 Lin YC, Tsai PH, Lin CY, Cheng CH, Lin TH, Lee KP, Huang KY, Chen SH, Hwang JJ, Kandaswami CC and Lee MT: Impact of flavonoids on matrix metalloproteinase secretion and invadopodia formation in highly invasive A431-III cancer cells. PLoS One 8: e71903, 2013.

36 He L, Wu Y, Lin L, Wang J, Chen Y, Yi Z, Liu M and Pang X: Hispidulin, a small flavonoid molecule, suppresses the angiogenesis and growth of human pancreatic cancer by targeting vascular endothelial growth factor receptor 2-mediated PI3K/ Akt/mTOR signaling pathway. Cancer Sci 102: 219-225, 2011.

37 Schindler R and Mentlein R: Flavonoids and vitamin E reduce the release of the angiogenic peptide vascular endothelial growth factor from human tumor cells. J Nutr 136: 1477-1482, 2006.

38 Zhang L, Li L, Jiao M, Wu D, Wu K, Li X, Zhu G, Yang L, Wang X, Hsieh JT and He D: Genistein inhibits the stemness properties of prostate cancer cells through targeting HedgehogGli1 pathway. Cancer Lett 323: 48-57, 2012.

39 Charepalli V, Reddivari L, Radhakrishnan S, Vadde R, Agarwal $\mathrm{R}$ and Vanamala JK: Anthocyanin-containing purple-fleshed potatoes suppress colon tumorigenesis via elimination of colon cancer stem cells. J Nutr Biochem 26: 1641-1649, 2015.

40 Mojsin M, Vicentic JM, Schwirtlich M, Topalovic V and Stevanovic M: Quercetin reduces pluripotency, migration and adhesion of human teratocarcinoma cell line NT2/D1 by inhibiting Wnt/beta-catenin signaling. Food Funct 5: 2564-2573, 2014.

41 Tang SN, Singh C, Nall D, Meeker D, Shankar S and Srivastava RK: The dietary bioflavonoid quercetin synergizes with epigallocathechin gallate (EGCG) to inhibit prostate cancer stem cell characteristics, invasion, migration and epithelialmesenchymal transition. J Mol Signal 5: 14, 2010.

42 Tang SN, Fu J, Nall D, Rodova M, Shankar S and Srivastava RK: Inhibition of sonic hedgehog pathway and pluripotency maintaining factors regulate human pancreatic cancer stem cell characteristics. Int J Cancer 131: 30-40, 2012.

43 Kao WT, Lin CY, Lee LT, Lee PP, Hung CC, Lin YS, Chen SH, Ke FC, Hwang JJ and Lee MT: Investigation of MMP-2 and -9 in a highly invasive A431 tumor cell sub-line selected from a Boyden chamber assay. Anticancer Res 28: 2109-2120, 2008.

44 Lin CY, Tsai PH, Kandaswami CC, Lee PP, Huang CJ, Hwang $\mathrm{JJ}$ and Lee MT: Matrix metalloproteinase-9 cooperates with transcription factor Snail to induce epithelial-mesenchymal transition. Cancer Sci 102: 815-827, 2011.

45 Heussen $\mathrm{C}$ and Dowdle EB: Electrophoretic analysis of plasminogen activators in polyacrylamide gels containing sodium dodecyl sulfate and copolymerized substrates. Anal Biochem 102: 196-202, 1980

46 Annabi B, Rojas-Sutterlin S, Laflamme C, Lachambre MP, Rolland Y, Sartelet H and Beliveau R: Tumor environment dictates medulloblastoma cancer stem cell expression and invasive phenotype. Mol Cancer Res 6: 907-916, 2008.

47 Justilien V, Regala RP, Tseng IC, Walsh MP, Batra J, Radisky ES, Murray NR and Fields AP: Matrix metalloproteinase-10 is required for lung cancer stem cell maintenance, tumor initiation and metastatic potential. PLoS One 7: e35040, 2012.

48 Matsuda K, Sato A, Okada M, Shibuya K, Seino S, Suzuki K, Watanabe E, Narita Y, Shibui S, Kayama T and Kitanaka C:
Targeting JNK for therapeutic depletion of stem-like glioblastoma cells. Sci Rep 2: 516, 2012.

49 Yoon CH, Kim MJ, Kim RK, Lim EJ, Choi KS, An S, Hwang SG, Kang SG, Suh Y, Park MJ and Lee SJ: c-Jun N-terminal kinase has a pivotal role in the maintenance of self-renewal and tumorigenicity in glioma stem-like cells. Oncogene 31: 46554666, 2012.

50 Kitanaka C, Sato A and Okada M: JNK Signaling in the Control of the Tumor-Initiating Capacity Associated with Cancer Stem Cells. Genes Cancer 4: 388-396, 2013.

51 Cohen M, Meisser A, Haenggeli L and Bischof P: Involvement of MAPK pathway in TNF-alpha-induced MMP-9 expression in human trophoblastic cells. Mol Hum Reprod 12: 225-232, 2006.

52 Rodda DJ, Chew JL, Lim LH, Loh YH, Wang B, Ng HH and Robson P: Transcriptional regulation of nanog by OCT4 and SOX2. J Biol Chem 280: 24731-24737, 2005.

53 Baccelli I and Trumpp A: The evolving concept of cancer and metastasis stem cells. J Cell Biol 198: 281-293, 2012.

$54 \mathrm{Yu}$ SC and Bian XW: Enrichment of cancer stem cells based on heterogeneity of invasiveness. Stem Cell Rev 5: 66-71, 2009.

55 Al-Hajj M, Wicha MS, Benito-Hernandez A, Morrison SJ and Clarke MF: Prospective identification of tumorigenic breast cancer cells. Proc Natl Acad Sci USA 100: 3983-3988, 2003.

56 Dick JE: Acute myeloid leukemia stem cells. Ann NY Acad Sci 1044: 1-5, 2005.

57 Li C, Heidt DG, Dalerba P, Burant CF, Zhang L, Adsay V, Wicha M, Clarke MF and Simeone DM: Identification of pancreatic cancer stem cells. Cancer Res 67: 1030-1037, 2007.

58 Collins AT, Berry PA, Hyde C, Stower MJ and Maitland NJ: Prospective identification of tumorigenic prostate cancer stem cells. Cancer Res 65: 10946-10951, 2005.

59 Rajasekhar VK, Studer L, Gerald W, Socci ND and Scher HI: Tumour-initiating stem-like cells in human prostate cancer exhibit increased NF-kappa B signalling. Nature Communications 22011.

60 Paulis YW, Soetekouw PM, Verheul HM, Tjan-Heijnen VC and Griffioen AW: Signalling pathways in vasculogenic mimicry. Biochim Biophys Acta 1806: 18-28, 2010.

61 Huang YT, Hwang JJ, Lee PP, Ke FC, Huang JH, Huang CJ, Kandaswami C, Middleton E, Jr. and Lee MT: Effects of luteolin and quercetin, inhibitors of tyrosine kinase, on cell growth and metastasis-associated properties in A431 cells overexpressing epidermal growth factor receptor. Br J Pharmacol 128: 999-1010, 1999.

62 Lee LT, Huang YT, Hwang JJ, Lee AY, Ke FC, Huang CJ, Kandaswami C, Lee PP, and Lee MT: Transinactivation of the epidermal growth factor receptor tyrosine kinase and focal adhesion kinase phosphorylation by dietary flavonoids: effect on invasive potential of human carcinoma cells. Biochemical pharmacology 67: 2103-2114, 2004.

63 Dingli D and Michor F: Successful therapy must eradicate cancer stem cells. Stem Cells 24: 2603-2610, 2006.

64 Tsai CH, Lin FM, Yang YC, Lee MT, Cha TL, Wu GJ, Hsieh SC and Hsiao PW: Herbal extract of Wedelia chinensis attenuates androgen receptor activity and orthotopic growth of prostate cancer in nude mice. Clin Cancer Res 15: 5435-5444, 2009.

Received August 31, 2016 Revised September 30, 2016 Accepted October 3, 2016 